\title{
Screening of Garden Pea Genotypes for High Temperature Tolerance Using Temperature Induction Response Technique
}

\author{
Deven Verma $^{1 *}$, T.S. Aghora ${ }^{1}$, Laxman Hunashikatti ${ }^{2}$ and A.T. Sadashiva ${ }^{1}$ \\ ${ }^{1}$ Division of Vegetable Crops, ICAR - IIHR, Bengaluru - 560089, India \\ ${ }^{2}$ Division of Plant Physiology and Biochemistry, ICAR - IIHR, Bengaluru - 560089, India \\ *Corresponding author
}

\begin{tabular}{|c|}
\hline Keywords \\
\hline $\begin{array}{l}\text { Garden pea, High } \\
\text { temperature } \\
\text { tolerance, TIR, } \\
\text { Lethal temperature, } \\
\text { Induction } \\
\text { temperature }\end{array}$ \\
\hline Article Info \\
\hline $\begin{array}{l}\text { Accepted: } \\
\text { 15 July } 2019 \\
\text { Available Online: } \\
10 \text { August } 2019\end{array}$ \\
\hline
\end{tabular}

\section{A B S T R A C T}

Garden pea is a cool season leguminous vegetable crop with a temperature requirement of $15-23^{\circ} \mathrm{C}$, for its optimum growth. Thus, it is mainly grown as a rabi season crop in India. Increased $\mathrm{CO}_{2}$ concentration in the environment has led to global warming. All the seedlings of pea lines were taken in uniformly after $48 \mathrm{~h}$ and grown in completely randomized design (CRD) block with three replications having twenty seedlings per replication. The experiment was conducted in the laboratory of Division of Plant Physiology and Biochemistry, ICAR- Indian Institute of Horticultural Research, Bengaluru. The standardization studies using 48 h old Azad P-1 seedlings revealed that optimum lethal and induction temperature were $43^{\circ} \mathrm{C}$ for 3 hours and $30-38^{\circ} \mathrm{C}$ for 3 hours, respectively. Screening of 32 garden pea germplasm lines using TIR technique resulted in identification of 10 tolerant lines (ArkaUttam, Arka Apoorva, IIHR 544, IIHR 13-1, IIHR 680, PMR 37, Swarna Mukti, KTP 4, and VRPMR 11) with the help of normal Z-distribution.

\section{Introduction}

Garden pea botanically known as Pisumsativum var. Hortense, which belongs to family Fabaceae. It is cool season leguminous vegetable crop which is mainly grown as a rabi season crop in India. It is extensively grown for seeds as well as pods and it can be consumed as fresh, canned, frozen or dry seeds in different areas of the world. The optimum temperature reported for the cultivation of garden pea ranges from $15^{\circ} \mathrm{C}$ to $23^{\circ} \mathrm{C}$ with a maximum temperature of $28^{\circ} \mathrm{C}$ (Lambert and Linck, 1958; Nonnecke et al., 1971).

They have been pretty well known for their nutritional values. Peas are an excellent source of protein, fibre, minerals and vitamins. The protein content of wrinkled-seeded pea cultivars is $26-33 \%$ while the protein in their smooth seeded counterparts is $23-31 \%$ 
(Cousin, 1997). Pea seed is a source of vitamins $\mathrm{A}, \mathrm{B}, \mathrm{C}$ and contains $35-40 \%$ starch, 4-7\% fibre and relatively high levels of lysine. This makes it an appropriate dietary complement to cereals. In addition to garden pea's ability to fix atmospheric nitrogen, they improve soil structure, and provide breaks for disease control, which ensures their importance in modern agricultural systems (McPhee, 2004; Martin et al., 2008).

Heat stress is defined as the rise in temperature above the optimum level for a period of time sufficient to cause irreversible damage to plant growth and development. It is a complex function of intensity, duration of exposure and rate of increase (Wahid et al., 2007). Heat stress is a serious threat to crop production worldwide (Hall, 2001). It has been found to be associated with decrease in primary root growth and distribution of laterals (Gladish and Rost, 1993). High temperature stress causes various morphological, physiological, and biochemical changes in plants. Hence, the present investigation is carried out to identify garden pea genotypes for high temperature tolerance using temperature induction response.

\section{Materials and Methods}

\section{Germplasm lines}

Thirty-two garden pea germplasm lines available with ICAR- Indian Institute of Horticultural Research, Bengaluru were screened for tolerance to high temperature. The one-year old seeds of all the lines were collected from division of vegetable crops. All the lines were listed in the Table 1.

\section{Experimental details}

The experiment was conducted in the laboratory of division of plant physiology and biochemistry, ICAR- Indian Institute of Horticultural Research, Bengaluru. As, the whole experiment was conducted in controlled environment, the temperature at which seeds were allowed to germinate as well as recover, after their exposure to high temperature, was $25^{\circ} \mathrm{C}$ (i.e. room temperature).

The seedlings, which were kept on watersoaked germination sheets in covered aluminium trays of $30 \times 3 \times 1 \mathrm{~cm}^{3}$ dimension, were exposed to high temperature stress in controlled growth chamber using a novel technique of Temperature Induction Response to screen genotypes for cellular level thermotolerance. All the seedlings of pea lines were taken in uniformly after $48 \mathrm{~h}$ and grown in completely randomized design (CRD) block with three replications having twenty seedlings per replication.

It was analyzed in ANOVA (Panse and Sukhatme, 1978) followed by $\mathrm{z}$ distribution to observed the genotypes for high temperature tolerance. Z- Distribution, based on z-score of per cent seedling survival and per cent reduction in growth, was employed to group the genotypes in accordance to their response to high temperature using the following formula:

$z$ score for \% seedling survival for variety $A=\frac{\text { Mean for var } \text { A }- \text { Over all mean }}{\text { Standard deviation }}$

The observation was recorded by using following formulas;

$$
\begin{aligned}
& \text { Percentseedlingsurvival }(\%)=\frac{\text { numberof seadingssurviwed }}{\text { number of seedlingskept }} \times 100 \\
& \text { Recoverygrowthof seedlings }(\mathrm{cm})=\frac{\text { totalgrowthofallthessedlingssurvived }}{\text { totalnumberof seedlingshept }} \\
& \text { Absolutecontrolgrowth }(\mathrm{cm})=\frac{\text { totalgrowthof sesdlingskeptascontrol }}{\text { totalnumber of seadingskeptascontrol }}
\end{aligned}
$$

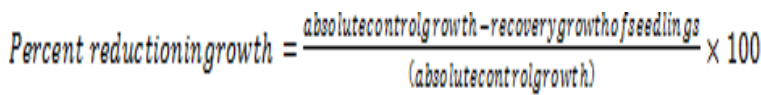




\section{Standardization of lethal temperature}

Lethal temperature is the temperature at which seedling survival was lesser than 15 per cent. To standardize the lethal temperature $\left(43^{\circ} \mathrm{C}\right)$ as well as its duration ( 3 hours), young and uniform seedlings were exposed to different temperatures for different durations in controlled growth chamber. After their exposure to high temperature, the seedlings were allowed to recover at room temperature for 72 hours. At the end of the recovery period, the per cent survival of seedlings was worked out. The temperature at which seedling survival per cent was around 15 per cent was fixed as lethal temperature for the experiment.

\section{Standardization of induction temperature}

Induction temperature is a sub lethal temperature at which when the seedlings are exposed, prior to lethal temperature, the maximum recovery growth was observed. To standardize the induction temperature as well as its duration, 48hour old seedlings of Azad P-1 were exposed to different temperatures for different durations, followed by lethal temperature. At the end of the recovery period the seedlings were observed for recovery growth, the set of treatment which showed maximum recovery growth was taken as optimum induction temperature.

\section{Results and Discussion}

\section{Standardization of lethal temperature}

The lethal temperature has been standardized by exposing two days old Azad P-1 seedlings to $48^{\circ} \mathrm{C}-3$ hour, $45^{\circ} \mathrm{C}-3$ hour, $44^{\circ} \mathrm{C}-3$ hour, $43^{\circ} \mathrm{C}-3$ hour and $42^{\circ} \mathrm{C}-3$ hour (Table 2). The results as shown in the table below depicts only $10 \%$ seedling survival in $43^{\circ} \mathrm{C}-3$ hour, whereas, at higher temperatures not a single seedling survived, but in case of the high temperature treatment where seedlings were exposed to $42^{\circ} \mathrm{C}-3$ hour, all the seedlings survived thus, from these results it was concluded that $43^{\circ} \mathrm{C}-3$ hour is standard lethal temperature for Azad P-1 seedlings. The percent reduction in growth over the absolute control, which can be used as other criteria for lethal temperature standardization along with per cent seedling survival, was $96.47 \%$ in this treatment.

High temperature response varies from crop to crop even from cultivar to cultivar, thus, standardization of lethal temperature is an important step prior to screening of germplasm lines in any given crop. In order to standardize lethal temperature, the seedlings should be exposed to different regimes of high temperature to look out for a high temperature at which seedling mortality is very high, but not 100 per cent. The standard definition for lethal temperature followed during the experiment goes as follows: the temperature at which the seedling survival per cent is between 10 and $15 \%$ (Srikanthbabu et al., 2002).

\section{Standardization of duration of lethal temperature}

After fixation of lethal temperature, identifying its duration is the next step, as temperature stress is a function of both intensity as well as duration. Thus, for standardization of duration of lethal temperature two days old Azad P-1 seedling were exposed to different durations ( 3 hours, 2hours 30 minutes and 2 hours) of lethal temperature i.e., $43^{\circ} \mathrm{C}$. The results obtained from this experiment have been presented in Table 3, where it shows that only $11.67 \%$ seedlings survived the after a recovery period of 72 hours. As, per cent seedling survival is an important criterion for fixation of lethal temperature and its duration, thus, $43^{\circ} \mathrm{C}$ for a duration of 3 hours was considered to be the 
optimum lethal temperature. The percent reduction in growth over the absolute control was $90.04 \%$ which ensures that the duration for the lethal temperature is ideal for the experiment. Significant difference has been observed between the treatments for per cent seedling survival/mortality.

\section{Standardization of induction temperature}

Induction temperature is a pre-lethal temperature treatment, which instead of killing the seedlings, induce the cellular mechanism to in the seedlings to tolerate lethal temperature. In other words, the seedlings exposed to induction temperature prior to lethal temperature has more chances of survival after the recovery phase of 72 hours and tend to have a good recovery growth. Thus, in order to standardize induction temperature in two days old Azad P-1 seedlings, they were exposed to different induction temperature treatments $\left(30-38^{\circ} \mathrm{C}-3\right.$ hour, $30-40^{\circ} \mathrm{C}-3$ hour and $30-40^{\circ} \mathrm{C}-2$ hour) followed by exposure to the defined lethal temperature i.e., $43^{\circ} \mathrm{C}$ for 3 hour (Table 3 ). For the treatments a gradual increment of temperature was maintained at a rate of $2.6^{\circ} \mathrm{C} /$ hour, $3.3^{\circ} \mathrm{C} /$ hour and $5^{\circ} \mathrm{C} /$ hour. All the seedlings belonging to different treatments were then allowed to recover at $25^{\circ} \mathrm{C}$ (room temperature) and data for $\%$ seedling survived, recovery growth of seedlings, absolute control growth and per cent reduction in growth was recorded. A non-induced control was maintained at $25{ }^{\circ} \mathrm{C}$ (room temperature). The maximum recovery growth (2.50) and per cent seedling survived $(95.00 \%)$ have been reported in $30-38^{\circ} \mathrm{C}(3 \mathrm{~h})$, due to which it was considered as standard induction temperature.

After the standardization of lethal temperature and its duration, the next important step to be followed is to standardize the gradual induction temperature protocol. An induction temperature is a semi-lethal temperature at which, the exposed seedlings induce cellular tolerance to the lethal temperature and thus, the recovery growth of such seedlings is enhanced as compared to their exposure to lethal temperature directly. For this experiment the standard definition used is as follows: the temperature at which recovery growth of seedlings is maximum after a recovery period of 72 hours (Srikanthbabu et al., 2002).

Table.1 List of garden pea germplasm lines used for screening for high temperature tolerance

\begin{tabular}{|l|l|l|l|}
\hline Sl. No. & Genotype & Sl. No. & Genotype \\
\hline $\mathbf{1 .}$ & Arka Priya & 17. & IIHR 680 \\
\hline $\mathbf{2 .}$ & ArkaAjit & 18. & IIHR 698 \\
\hline $\mathbf{3 .}$ & Arka Pramod & 19. & NDVP 24 \\
\hline $\mathbf{4 .}$ & ArkaUttam & 20. & PMR 37 \\
\hline $\mathbf{5 .}$ & ArkaSampoorna & 21. & PMR 53 \\
\hline $\mathbf{6 .}$ & Arka Apoorva & 22. & Swarna Mukti \\
\hline $\mathbf{7 .}$ & Arka Tapas & 23. & KTP-4 \\
\hline $\mathbf{8 .}$ & Arka Chaitra & 24. & PC-531 \\
\hline $\mathbf{9 .}$ & Arka Karthik & 25. & Kashmir 13-1 \\
\hline $\mathbf{1 0 .}$ & IIHR 1-2 & 26. & VRPMR-10 \\
\hline $\mathbf{1 1 .}$ & IIHR 13-1 & 27. & VRPMR-11 \\
\hline $\mathbf{1 2 .}$ & IIHR 13-15 & 28. & Azad P-1 \\
\hline $\mathbf{1 3 .}$ & IIHR 13-18 & 29. & PM Var-7 \\
\hline $\mathbf{1 4 .}$ & IIHR 13-22 & 30. & Oregon Sugar \\
\hline $\mathbf{1 5}$. & IIHR 13-29 & 31. & VRP 22 \\
\hline $\mathbf{1 6 .}$ & IIHR 544 & 32. & PB 29614 X 7-6 \\
\hline
\end{tabular}


Table.2 Standardization of lethal temperature for 48 h old Azad P-1 seedlings

\begin{tabular}{|c|c|c|c|c|c|}
\hline $\begin{array}{c}\text { Temp } \\
{ }^{\circ} \mathbf{C}\end{array}$ & $\begin{array}{c}\text { Duration } \\
\text { (hours) }\end{array}$ & $\begin{array}{c}\text { \% seedling survived } \\
\text { after } \mathbf{7 2 ~ h}\end{array}$ & $\begin{array}{c}\text { Recovery } \\
\text { growth of } \\
\text { seedlings }\end{array}$ & $\begin{array}{c}\text { Absolute } \\
\text { Control } \\
\text { growth }\end{array}$ & $\begin{array}{c}\text { Per cent reduction } \\
\text { in growth }\end{array}$ \\
\hline $\mathbf{4 8 . 0}$ & 3.0 & $0.00(0.00)$ & 0.00 & 7.22 & $100.00(90.00)$ \\
\hline $\mathbf{4 5 . 0}$ & 3.0 & $0.00(0.00)$ & 0.00 & 6.45 & $100.00(90.00)$ \\
\hline $\mathbf{4 4 . 0}$ & 3.0 & $0.00(0.00)$ & 0.00 & 7.32 & $100.00(90.00)$ \\
\hline $\mathbf{4 3 . 0}$ & 3.0 & $10.00(18.04)$ & 0.26 & 7.45 & $96.47(79.19)$ \\
\hline $\mathbf{4 2 . 0}$ & 3.0 & $100.00(90.00)$ & 4.42 & 8.06 & $45.12(42.13)$ \\
\hline Mean $\mathbf{\pm} \mathbf{S E m}$ & $22.00(21.61 \pm 1.28)$ & $0.94 \pm 0.21$ & 7.3 & $88.32(78.27 \pm 1.57)$ \\
\hline CD at $\mathbf{1 \%}$ & 5.72 & 0.95 & - & 7.05 \\
\hline \multicolumn{2}{|c|}{ CV $\mathbf{( \% )}$} & 10.23 & 39.15 & - & 3.48 \\
\hline
\end{tabular}

Table.3 Standardization of duration of lethal temperature for $48 \mathrm{~h}$ old Azad P- 1 seedlings

\begin{tabular}{|c|c|c|c|c|c|}
\hline $\begin{array}{c}\text { Temp } \\
{ }^{\circ} \mathbf{C}\end{array}$ & $\begin{array}{c}\text { Duratio } \\
\mathbf{n} \\
\text { (hours) }\end{array}$ & $\begin{array}{c}\text { \% seedling } \\
\text { survived after 72 h }\end{array}$ & $\begin{array}{c}\text { Recovery } \\
\text { growth of } \\
\text { seedlings }\end{array}$ & $\begin{array}{c}\text { Absolute } \\
\text { Control } \\
\text { growth }\end{array}$ & $\begin{array}{c}\text { Per cent reduction } \\
\text { in growth }\end{array}$ \\
\hline $\mathbf{4 3 . 0}$ & 3.0 & $11.67(19.30)$ & 0.64 & 6.39 & $90.04(72.76)$ \\
\hline $\mathbf{4 3 . 0}$ & 2.5 & $41.67(40.15)$ & 1.66 & 7.22 & $76.96(61.50)$ \\
\hline $\mathbf{4 3 . 0}$ & 2.0 & $93.33(78.08)$ & 1.39 & 5.17 & $73.05(58.79)$ \\
\hline Mean $\mathbf{\pm}$ SEm & $48.89(45.84 \pm 4.69)$ & $1.23 \pm 0.27$ & 6.26 & $80.02(64.35 \pm 3.57)$ \\
\hline CD at $\mathbf{1 \%}$ & 24.57 & 1.44 & - & 18.72 \\
\hline CV $(\%)$ & 17.71 & 38.50 & - & 9.61 \\
\hline
\end{tabular}

Table.4 Standardization of induction temperature followed by exposure to lethal temperature of $43{ }^{\circ} \mathrm{C}$ for 3 hours using $48 \mathrm{~h}$ old seedlings of Azad P-1

\begin{tabular}{|c|c|c|c|c|}
\hline $\begin{array}{l}\text { Induction Temp } \\
\quad\left({ }^{\circ} \mathrm{C}\right) \text { and } \\
\text { Duration (hours) }\end{array}$ & $\begin{array}{c}\text { \% seedling survived } \\
\text { after } 72 \mathrm{~h}\end{array}$ & $\begin{array}{l}\text { Recovery } \\
\text { growth of } \\
\text { seedlings }\end{array}$ & $\begin{array}{l}\text { Absolute } \\
\text { Control } \\
\text { growth }\end{array}$ & $\begin{array}{l}\text { Per cent reduction in } \\
\text { growth }\end{array}$ \\
\hline $30-38^{\circ} \mathrm{C}(3 \mathrm{~h})$ & $95.00(79.53)$ & 2.50 & 7.97 & $68.59(55.98)$ \\
\hline $30-40^{\circ} \mathrm{C}(3 \mathrm{~h})$ & $43.33(40.95)$ & 1.79 & 7.97 & $77.57(61.74)$ \\
\hline $30-40^{\circ} \mathrm{C}(2 \mathrm{~h})$ & $65.00(54.82)$ & 2.00 & 7.97 & $74.85(60.01)$ \\
\hline Mean \pm SEm & $67.78(58.43 \pm 7.16)$ & $2.10 \pm 0.28$ & 7.97 & $73.67(59.24 \pm 2.22)$ \\
\hline CD at $1 \%$ & 37.51 & 1.44 & - & 11.62 \\
\hline CV (\%) & 21.21 & 22.73 & - & 6.48 \\
\hline
\end{tabular}


Table.5 Screening of 32 garden pea germplasm lines for high temperature tolerance at seedling stage

\begin{tabular}{|c|c|c|c|c|}
\hline Lines & $\begin{array}{l}\text { Per cent seedlings } \\
\text { survived }\end{array}$ & $\begin{array}{l}\text { Recovery } \\
\text { growth of } \\
\text { seedlings }\end{array}$ & $\begin{array}{c}\text { Absolute } \\
\text { Control } \\
\text { growth }\end{array}$ & $\begin{array}{l}\text { Per cent reduction } \\
\text { in growth }\end{array}$ \\
\hline IIHR 698 & $43.33(40.62)$ & 0.98 & 16.69 & $94.13(77.68)$ \\
\hline Kashmir 13-1 & $45.00(42.07)$ & 0.67 & 9.89 & $93.24(76.60)$ \\
\hline IIHR 13-1 & $96.67(83.85)$ & 3.77 & 12.07 & $68.75(56.02)$ \\
\hline IIHR 680 & $100.00(90.00)$ & 3.60 & 14.15 & $74.56(59.77)$ \\
\hline IIHR 13-22 & $48.89(44.78)$ & 1.40 & 8.74 & $83.98(68.80)$ \\
\hline Arka Pramod & $38.33(37.58)$ & 1.13 & 4.94 & $77.14(66.41)$ \\
\hline NDVP 24 & $48.33(44.03)$ & 1.20 & 9.19 & $86.94(69.63)$ \\
\hline VRPMR 11 & $65.00(54.02)$ & 1.49 & 7.81 & 80.87 (64.93) \\
\hline PB 29614 X 7-6 & $20.00(26.44)$ & 0.11 & 7.95 & $98.60(83.24)$ \\
\hline 9/2014 PMVAR 7 & $45.00(41.94)$ & 0.57 & 7.42 & $92.34(74.13)$ \\
\hline ArkaUttam & $70.00(63.28)$ & 1.37 & 5.75 & $76.14(63.57)$ \\
\hline KTP 4 & $71.67(58.04)$ & 3.19 & 7.53 & $57.67(49.56)$ \\
\hline IIHR 13-15 & $21.67(27.27)$ & 0.59 & 11.24 & $94.74(78.49)$ \\
\hline Arka Karthik & $25.00(29.79)$ & 0.29 & 3.55 & $91.92(74.56)$ \\
\hline Arka Apoorva & $63.33(52.89)$ & 3.03 & 4.54 & $33.30(35.02)$ \\
\hline ArkaAjit & $43.33(41.09)$ & 1.34 & 6.46 & $79.21(64.62)$ \\
\hline Arka Chaitra & $75.00(60.29)$ & 1.40 & 7.94 & $82.43(65.80)$ \\
\hline IIHR 13-18 & $66.67(55.34)$ & 0.40 & 6.61 & $93.95(76.18)$ \\
\hline Swarna Mukti & $93.33(81.14)$ & 1.52 & 7.26 & $79.02(63.36)$ \\
\hline ArkaSampoorna & $68.89(56.40)$ & 0.60 & 7.01 & $91.45(73.02)$ \\
\hline VRPMR 10 & $61.67(52.38)$ & 0.80 & 11.07 & $92.74(74.92)$ \\
\hline PMR 53 & $55.00(47.86)$ & 1.36 & 7.20 & $81.09(64.20)$ \\
\hline IIHR 1-2 & $75.00(60.24)$ & 0.75 & 6.57 & $88.60(70.34)$ \\
\hline PC 531 & $58.33(49.81)$ & 0.71 & 6.15 & $88.42(70.21)$ \\
\hline PMR 37 & $98.33(85.68)$ & 1.58 & 6.33 & $75.02(60.42)$ \\
\hline IIHR 13-29 & $13.33(17.59)$ & 0.13 & 14.27 & $99.07(85.45)$ \\
\hline VRP 22 & $60.00(50.77)$ & 0.83 & 5.29 & $84.31(66.79)$ \\
\hline Oregon Sugar & $45.00(42.10)$ & 0.47 & 7.84 & $93.96(75.98)$ \\
\hline Arka Tapas & $56.67(49.02)$ & 0.45 & 5.27 & $91.42(73.61)$ \\
\hline IIHR 544 & $60.00(51.00)$ & 1.52 & 8.50 & $82.17(65.26)$ \\
\hline Azad P- 1 & $96.67(81.37)$ & 2.73 & 4.64 & $41.09(39.76)$ \\
\hline Arka Priya & $61.67(52.38)$ & 0.88 & 5.49 & $84.06(69.17)$ \\
\hline Mean \pm SEm & $59.10(52.22 \pm 8.15)$ & $1.28 \pm 0.45$ & 7.98 & $82.26(67.42 \pm 5.21)$ \\
\hline CD at $1 \%$ & 23.09 & 1.27 & - & 14.76 \\
\hline CV (\%) & 27.04 & 60.49 & - & 13.39 \\
\hline
\end{tabular}


Table.6 Classification of different garden pea germplasm lines into different categories based on normal z-distribution

\begin{tabular}{|c|c|c|}
\hline $\begin{array}{c}\text { High temperature } \\
\text { tolerant genotypes at } \\
\text { seedling stage (IV } \\
\text { quadrant) }\end{array}$ & $\begin{array}{c}\text { Genotypes intermediate } \\
\text { in response to high } \\
\text { temperature stress at } \\
\text { seedling stage (I and III } \\
\text { quadrant) }\end{array}$ & $\begin{array}{c}\text { High temperature } \\
\text { susceptible genotypes at } \\
\text { seedling stage (II } \\
\text { quadrant) }\end{array}$ \\
\hline ArkaUttam & Arka Chaitra & Arka Tapas \\
\hline Arka Apoorva & Arka Priya & Arka Kartik \\
\hline IIHR 544 & Arka Pramod & IIHR 13-15 \\
\hline IIHR 13-1 & ArkaAjit & IIHR 13-22 \\
\hline IIHR 680 & ArkaSampoorna & IIHR 698 \\
\hline PMR 37 & IIHR 13-18 & IIHR 13-29 \\
\hline Swarna Mukti & IIHR 1-2 & PMVAR 7 \\
\hline KTP 4 & PMR 53 & Oregon Sugar \\
\hline VRPMR 11 & VRPMR 10 & PC 531 \\
\hline Azad Pea 1 & VRP 22 & PB29614 X 7-6 \\
\hline & & Kashmir 13-1 \\
\hline & & NDVP 24 \\
\hline
\end{tabular}

Fig.1 Normal z-distribution of garden pea germplasm for heat tolerance or susceptibility

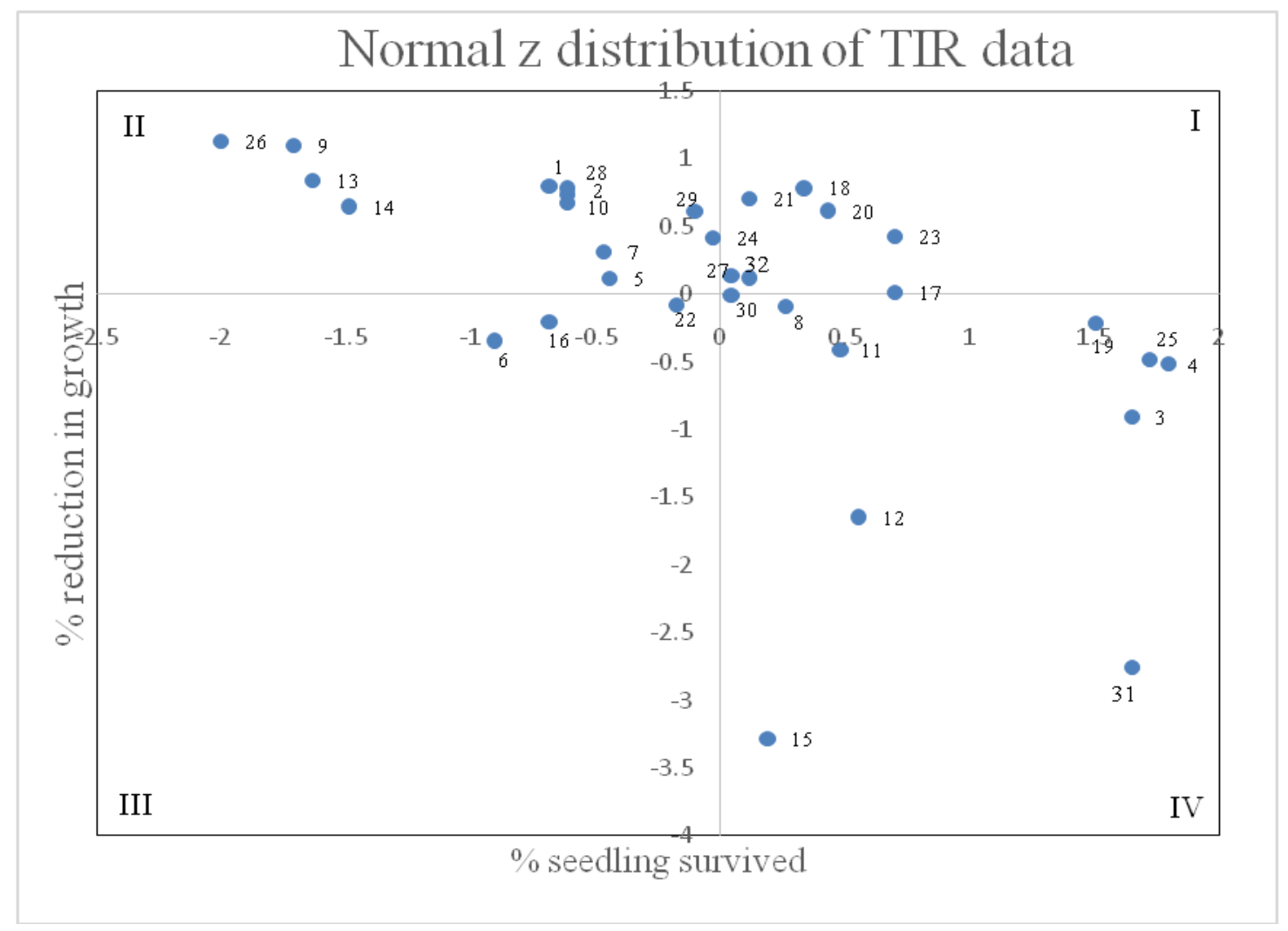


Screening for high temperature tolerance using TIR technique

The $48 \mathrm{~h}$ old seedlings of all the 32 germplasm lines were exposed to $30-38^{\circ} \mathrm{C}(3$ h) induction temperature followed by $43^{\circ} \mathrm{C}$ (3h) lethal temperature to screen them for cellular tolerance to high temperature stress. The observations recorded at the end of recovery period showed significant differences in terms of percent seedling survival, recovery growth of seedlings and per cent reduction in growth over control (Table 4) for the different pea genotypes.

Among the genotypes IIHR 680 showed 100 percent seedling survival followed by genotype PMR 37 (98.33\%), IIHR 13-1 (96.67\%) and Swarna Mukti (93.33\%). The least percent survival of $13.33 \%$ was observed in IIHR 13-29 followed by PB 29614 X 7-6 (20\%), IIHR 13-15 (21.67\%), Arka Karthik (25\%) and Arka Pramod (38.33). Recovery growth of seedlings has been recorded highest in IIHR 13-1 $(3.77 \mathrm{~cm})$ followed by IIHR 680 $(3.60 \mathrm{~cm})$, KTP $4(3.19 \mathrm{~cm})$ and Arka Apoorva $(3.03 \mathrm{~cm})$, whereas, minimum values were observed in PB 29614 X 7-6 $(0.11 \mathrm{~cm})$, IIHR 13-29 $(0.13 \mathrm{~cm})$ and Arka Karthik $(0.29 \mathrm{~cm})$. Arka Apoorva showed the least per cent reduction in growth over control $(33.30 \%)$ followed by KTP $4(57.67 \%)$ and IIHR 13-1 (68.75).

The results obtained from screening experiment of different germplasms shows a huge variation in their thermotolerance, which may be due to different stress adaptive mechanisms. The results have revealed a range of 13.33 per cent seedling survival to 100 per cent seedling survival, the same has been observed in case of recovery growth of seedlings as well as the per cent reduction in growth. Similar kind of genetic variability for cellular tolerance has been reported by several researchers (Srikanthbabu et al., 2002:
Bharani, 2014; Chaukhande et al., 2017; Sujatha et al., 2018).

Assessment of garden pea lines for their reaction to high temperature stress using $z$ distribution analysis

Based on percentage seedling survived and percentage reduction in growth obtained from the screening results, z-score was calculated for all the 32 garden pea germplasm lines (Table 5), the genetic variability of 32 pea genotypes to heat tolerance was assessed by plotting their z-score on normal z-distribution graph (Figure 1). Genotypes were classified in three different categories, viz., high temperature tolerant (IV quadrant), moderately susceptible (I and III quadrant) and susceptible(II quadrant) based on $\mathrm{z}-$ analysis. The normal $\mathrm{Z}$ distribution revealed that the genotypes: ArkaUttam, Arka Apoorva, IIHR 544, IIHR 13-1, IIHR 680, PMR 37, Swarna Mukti, KTP 4, VPPMR 11 are tolerant to high temperature whereas Arka Chaitra, Arka Priya, Arka Pramod, ArkaAjit, ArkaSampoorna, IIHR 13-18, IIHR 1-2, PMR 53, VRPMR 10 and VRP 22 are moderately susceptible. Arka Tapas, Arka Karthik, IIHR 13-15, IIHR 13-22, IIHR 698, IIHR 13-29, PMVAR 7, PC 531, PB29614 X 7-6, Kashmir 13-1 and NDVP 24 were categorized as susceptible to high temperature (Table 6).

The normal Z-distribution technique, used for classification of genotypes into different groups based on parameters such as percentage seedling survived and percentage reduction in growth has been reported as promising by other researchers also, such as Srikanthbabu et al., (2002) (garden pea), Chaukhande et al., (2017) (French bean), etc.

The standardization studies using $48 \mathrm{~h}$ old Azad P-1 seedlings revealed that optimum lethal and induction temperature were $43^{\circ} \mathrm{C}$ for 3 hours and $30-38^{\circ} \mathrm{C}$ for 3 hours, 
respectively. Screening of 32 garden pea germplasm lines using TIR technique resulted in identification of 10 tolerant lines (ArkaUttam, Arka Apoorva, IIHR 544, IIHR 13-1, IIHR 680, PMR 37, Swarna Mukti, KTP 4 , and VRPMR 11) by the help of normal Zdistribution.

\section{References}

Bharani, H.K. (2014). Evaluation of sunflower (Helianthus annuus L.) genotypes for temperature stress tolerance. M.Sc. Thesis. Department of Genetics and Plant Breeding. University of Agricultural Sciences, GKVK, Bangalore.

Chaukhande, P., Aghora, S., Laxman, H., Biradar, G. and Singh, B. (2017). Evaluation of French bean genotypes for high temperature tolerance using Temperature Induction Response (TIR) technique. Vegetable Science, 44 (2): 20-25.

Cousin, R. (1997). Peas (Pisum sativum L.). Field Crops Research, 53: 111-130.

Gladish, D.K. and Rost, T.L. (1993). The effect of temperature on primary root growth dynamics and lateral roots distribution in garden pea (Pisum sativum L., "Alaska"). Environmental and Experimental Botany, 33: 243-258.

Hall, A.E. (2001). Crop Responses to Environment. CRC Press LLC, Boca Raton, Florida.

Lambert, R.G. and Linck, A.J. (1958). Effects of high temperature on yield of peas. Plant Physiology, 33: 347-350.

Martin-Sanz, A., Luis P.J., Perez, V.M. and
Caminero, C. (2011). Identification of pathovars and races of Pseudomonas syringae, the main causal agent of bacterial disease in pea in North-Central Spain, and the search for disease resistance. European Journal of Plant Pathology, 129(1): 57-69.

McPhee, K. (2004). Garden Pea. Journal of New Seeds, 6(2): 277-288.

Nonnecke, I.L., Adedipe, N.O. and Ormrod, D.P. (1971). Temperature and humidity effects on the growth and yield of pea cultivars. Canadian Journal of Plant Science, 51: 479-484.

Panse, V.G. and Sukhatme, P.V. (1978). Statistical Methods for Agricultural Workers. Information Systems Division, National Agricultural Library. Indian Council of Agricultural Research.

Srikanthbabu, V., Ganesh, K., Krishnaprasad, B.T., Gopalakrishna, R., Savitha, M. and Udayakumar, M. (2002). Identification of pea genotypes with enhanced thermotolerance using temperature induction response technique (TIR). Journal of Plant Physiology, 159(5): 535-545.

Sujatha, B., Sirisha, P. and Bharathi, Y.V. (2018). Screening of acquired thermotolerant ragi [Eluesina coracana (L.) Gaertn] genotypes using T.I.R. technique. International Journal of Plant Sciences, 13 (1): 165-170.

Wahid, A., Gelani, S., Ashraf, M. and Foolad, M.R. (2007). Heat tolerance in plants: An overview. Environmental and Experimental Botany, 61: 199-223.

\section{How to cite this article:}

Deven Verma, T.S. Aghora, Laxman Hunashikatti and Sadashiva, A.T. 2019. Screening of Garden Pea Genotypes for High Temperature Tolerance Using Temperature Induction Response Technique. Int.J.Curr.Microbiol.App.Sci. 8(08): 2065-2073. doi: https://doi.org/10.20546/ijcmas.2019.808.241 